Annals of Warsaw University of Life Sciences - SGGW

Land Reclamation No 43 (1), 2011: 3-11

(Ann. Warsaw Univ. of Life Sci. - SGGW, Land Reclam. 43 (1), 2011)

\title{
Participatory water resources planning and management in an Agriculturally Intensive Watershed in Quebec, Canada using Stakeholder Built System Dynamics Models
}

\author{
JAN ADAMOWSKI, JOHANNES HALBE \\ Department of Bioresource Engineering, Faculty of Agricultural and Environmental Sciences, McGill \\ University, Canada
}

\begin{abstract}
Participatory water resources planning and management in an Agriculturally Intensive Watershed in Quebec, Canada using Stakeholder Built System Dynamics Models. The participation of stakeholders is an important component in integrated and adaptive watershed planning and management. In Quebec, Canada watershed organizations are in the process of implementing participatory based watershed planning and management schemes. However, there is a lack of simple and readily implementable frameworks and methods to explicitly involve stakeholders, as well as integrate physical and social processes, in watershed planning and management in Quebec. This paper describes the application of the first three stages of a newly proposed five stage stepwise Participatory Model Building framework that was developed to help facilitate the participatory investigation of problems in watershed planning and management through the use of qualitative system dynamics models. In the agriculturally intensive Du Chene watershed in Quebec, eight individual stakeholder interviews were conducted in cooperation with the local watershed organization to develop qualitative system dynamics models that represent the main physical and social processes in the Du Chene watershed. The proposed Participatory Model Building framework was found to be accessible for all the interviewees, and was deemed to be very useful by the watershed organization to develop an overview of the different perspectives of the main stakeholders in the watershed, as well as to help develop watershed policies and strategies. The individual qualitative system dynamics models developed in this study can subsequently be converted into an overall group built system dynamics model (describing the socio-economic-political components of the watershed), which in turn can be quantified
\end{abstract}

and coupled with a physically based model such as HEC-HMS or SWAT (describing the physical components of the watershed).

Key words: watershed planning and management, stakeholders, agriculture, system thinking.

\section{INTRODUCTION}

Stakeholder participation in watershed management has become important for a number of reasons. First, the traditional engineering and sectoral based approach that aims to increase the supply of water to meet increasing water demand is no longer feasible or sustainable in many parts of the world. Second, the necessity for a more 'holistic' approach to watershed management means that it is necessary to explicitly consider environmental, economic, and social aspects of watersheds. And third, centralized decision making has frequently resulted in local stakeholders not being willing to help implement new policies and strategies since they were not involved in their development. These types of problems can be avoided by analyzing watershed issues in conjunction with the main stakeholders in a watershed. In this way, stakeholders learn about different perspectives, and are able to include their points of view. 
The implementation of true participatory watershed management is not common in most parts of the world. In 2002, Quebec implemented the Quebec Water Policy, which stipulates that watershed organizations are responsible for the planning and management of watersheds in the province. As part of this new mandate, watershed organizations in Quebec are responsible for the implementation of integrated and participatory watershed management practices in forty priority watersheds in the province. However, there is a lack of simple and readily implementable methods to explicitly involve stakeholders, as well as integrate physical and social processes, in watershed planning and management in Quebec. This paper describes the application of the initial stages of a newly proposed Participatory Model Building stepwise framework (Adamowski and Halbe 2010; Halbe, Pahl-Wostl, and Adamowski, in review) that was developed to help facilitate the participatory investigation of problems in watershed planning and management through the use of qualitative system dynamics models. Several researchers have explored the use of system dynamics models for watershed modeling (e.g., Simonovic and Fahmy 1999). However, apart from Adamowski et al. (2010), no researchers have explored both the explicit integration of stakeholders in the development and use of system dynamics models, as well as mechanisms to faciliate long-term stakeholder invovlement, in participatory watershed planning and management.

The proposed participatory modeling process can be applied in a stepwise fashion by gradually adapting it to site specific needs. Beginning with low cost and short-term approaches for stakeholder involvement, the proposed participatory process can be broadened step-by-step to deeper and more long-term cooperation that results in social learning as well as more integrated and adaptive watershed management.

\section{STUDY SITE: DU CHÊNE WATERSHED, QUEBEC, CANADA}

Located in southern Quebec, the Du Chêne watershed is one of the 40 'priority' watersheds in Quebec, Canada. It is a medium sized watershed $\left(1.252 \mathrm{~km}^{2}\right)$ with intensive agriculture that has resulted in pollution problems and increasing water demands. Based on the new Québec Water Policy of 2002, watershed organizations in Quebec are responsible for the implementation of integrated and participatory management principles for forty priority watersheds in the province. As part of this, each watershed organization is responsible for the development and implementation of a Master Plan for the watershed. The watershed organizations in Quebec are composed of representatives of stakeholder groups in the watershed. The government representatives act as facilitators and provide scientific and technical support, but do not have voting or decision powers.

\section{METHODOLOGY}

\section{Qualitative system dynamics models}

Qualitative system dynamics models, or Causal Loop Diagrams (CLDs), are tools that can be used to qualitatively probe 
a system such as a watershed. CLDs can help to depict a watershed's structure, as well as mark time delays. In CLDs, the main elements of a watershed can be connected via arrows which together form causal chains. The functional polarity of a link between variables is shown with positive $(+)$ or negative $(-)$ signs. User friendly system dynamics software tools such as VENSIM or STELLA can be used for both qualitative and quantitative system analysis (isee systems, 2009; Ventana Systems, 2009). In this study, the STELLA software was used to develop the qualitative system dynamics models.

\section{Proposed participatory model building framework (PMB)}

The proposed five stage stepwise Participatory Model Building framework provides a 'path' towards long-term participatory planning and management in a watershed, and is aimed at overcoming barriers to the operationalization of integrated and adaptive watershed management. Each of the five stages of the proposed PMB framework is an independent stage that provides a stepwise process for watershed managers to help implement participatory watershed management.

Figure 1 illustrates the five stages of the Participatory Model Building framework. The process begins with methods that do not necessitate high financial investments or mediation skills (Stages 1 to 3). In this way, a watershed organization can obtain insights about the need for and applicability of the PMB framework for their particular watershed without investing a significant amount of funds or time. If everything progress positively, the process proceeds to the 'involvement' stage (Stage 4), where watershed stakeholders meet, build a group model and discuss the causes and consequences of a particular watershed problem as well as policies and strategies to help resolve the issue. In the long term (Stage 5), the goal

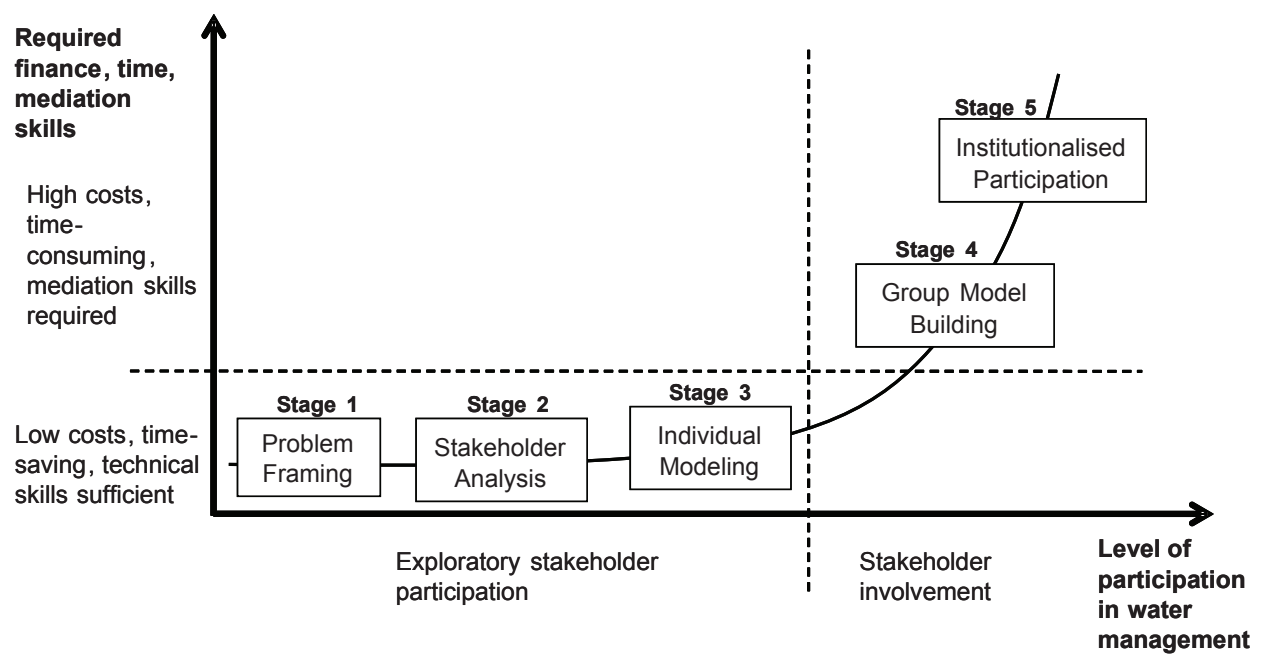

FIGURE 1. The Participatory Model Building (PMB) Framework (Halbe, Pahl-Wostl, Adamowski, in review) 
is the integration of learning processes in institutional structures in the watershed to help facilitate effective social learning processes. The five stages of the PMB framework are (Fig. 1):

Stage 1 Problem framing: Problem framing methods are used to analyze specific watershed policy or strategy issues from multiple angles.

Stage 2 Stakeholder analysis: Stage 1 is connected with the second stage (stakeholder analysis), which identifies and explores actors belonging to the specific problem situation in the watershed.

Stage 3 Individual modeling: The individual model building stage is based on the results of the first two stages. This stage investigates the mental models of stakeholders via the development of CLDs (qualitative system dynamics models) with individual stakeholder interviews.

Stages 1 through 3 do not necessitate high levels of finances and time, and can be managed by staff in watershed organizations. However, stages 4 and 5 require a high level of knowledge in mediation and conflict resolution, are more expensive and time consuming, and necessitate long-term planning, commitment and management.

Stage 4 Group model building: In stage four, the stakeholder group meets as a group and develops a comprehensive CLD together. Following this, the qualitative model is quantified via mathematical relations, which allows stakeholders to analyze the dynamic behavior of the watershed, and to test scenarios to help develop effective and sustainable policies and strategies. After policies and strategies are selected, they are imple- mented and monitored, and their success is evaluated. Gaps between observed behavior in the watershed and model simulation results point to problems with the model. The stakeholder group can then revise the model based on these new insights. In addition, after the quantified group built CLD (or quantitative system dynamics model) is developed, it can be coupled with a physically based model such as HEC-HMS or SWAT.

\section{Stage 5 Institutionalized participation:}

The institutionalization of the above described learning processes is necessary for long-term social learning. This stage is the highest form of participation and it relies on fundamental changes in watershed management paradigms and institutional frameworks in the watershed.

\section{RESULTS AND DISCUSSION}

The exploratory phase of the proposed Participatory Model Building framework (Stages 1-3) was tested in a case study in the Du Chene watershed in Québec, Canada. As such, only stages 1 to 3 (i.e. up to and including individual modeling) will be described. This research project will be expanded to stages 4 and 5 (i.e. the development and use of the quantitative system dynamics model, and the embedment of the process in institutional structures in the watershed) in the near future.

\section{Stages 1 (Problem framing) and 2 (Stakeholder analysis):}

In three days, eight stakeholder interviews were conducted in the Du Chęne Watershed in Quebec with the cooperation and involvement of the Du Chene watershed organization. The watershed 
organization stakeholders in the Du Chęne determined that the major issue in the watershed was the problem of declining water quality (mainly due to eutrophication and chemical contamination). The sources of water pollution are thought to originate from the agriculture, forestry, and municipal sectors. However, the exact pathways and quantities are still unclear, and further research was deemed necessary. As such, the watershed organization decided to explore the usefulness of the proposed PMB framework to explore this issue.

The choice for interviewees represented the composition of the Du Chene watershed organization, namely the community ( 2 representatives), municipality (3 representatives) and economic sectors (3 representatives). The interviewees represented the agriculture, municipal, and forestry sectors, as well as environmental and citizen perspectives.

\section{Stage 3 (Individual modeling):}

The purpose of the individual stakeholder interviews was to improve relations between stakeholders in the Du Chęne watershed, and to learn about the different perspectives on the causes, consequences, and possible solutions related to the water quality problem in the watershed. In the past, insights from stakeholder meetings were limited. As such, the watershed organization thought that individual stakeholder interviews and the development of individual stakeholder CLDs would be more suitable to explore the personal perspectives of stakeholders instead of engaging in discussions in a large group.

The method of systems thinking was used to structure the interviews by focusing explicitly on causes, consequences, and proposed policies and strategies related to the water quality problem in the Du Chene watershed. Causal Loop Diagrams were built by each interviewee with support from the second author as well as the two watershed directors of the $\mathrm{Du}$ Chęne watershed organization. The two watershed directors were trained on how to apply the PMB framework and develop CLDs in an earlier session.

The interviewees represented the agriculture, municipal, and forestry sectors, as well as environmental and citizen perspectives. Three example models are shown in Figures 2, 3, and 4 from the agricultural, forestry and municipal sectors, respectively. The red variable is the problem variable (i.e., "water quality"), and the green variables are proposed solutions. The models show different perspectives on the problem of water quality with some complementary, redundant, and controversial elements:

\section{Redundant elements:}

All models highlight the impact of agriculture and municipal wastewater on the water quality problem. Changes in cultivation methods were considered helpful to reduce chemical exposure and sediment load from agricultural sites in the Du Chene watershed.

\section{Controversial elements:}

From the perspective of farmers in the Du Chene watershed, large scale organic farming will increase the impact of the agricultural sector on water quality. This is due to a need for more tillage for organic farming than is required for conventional agriculture. As a result, the farmers believe that erosion is higher for organic farming compared to conventional farming. The representative of the farming sector in the Du Chene 


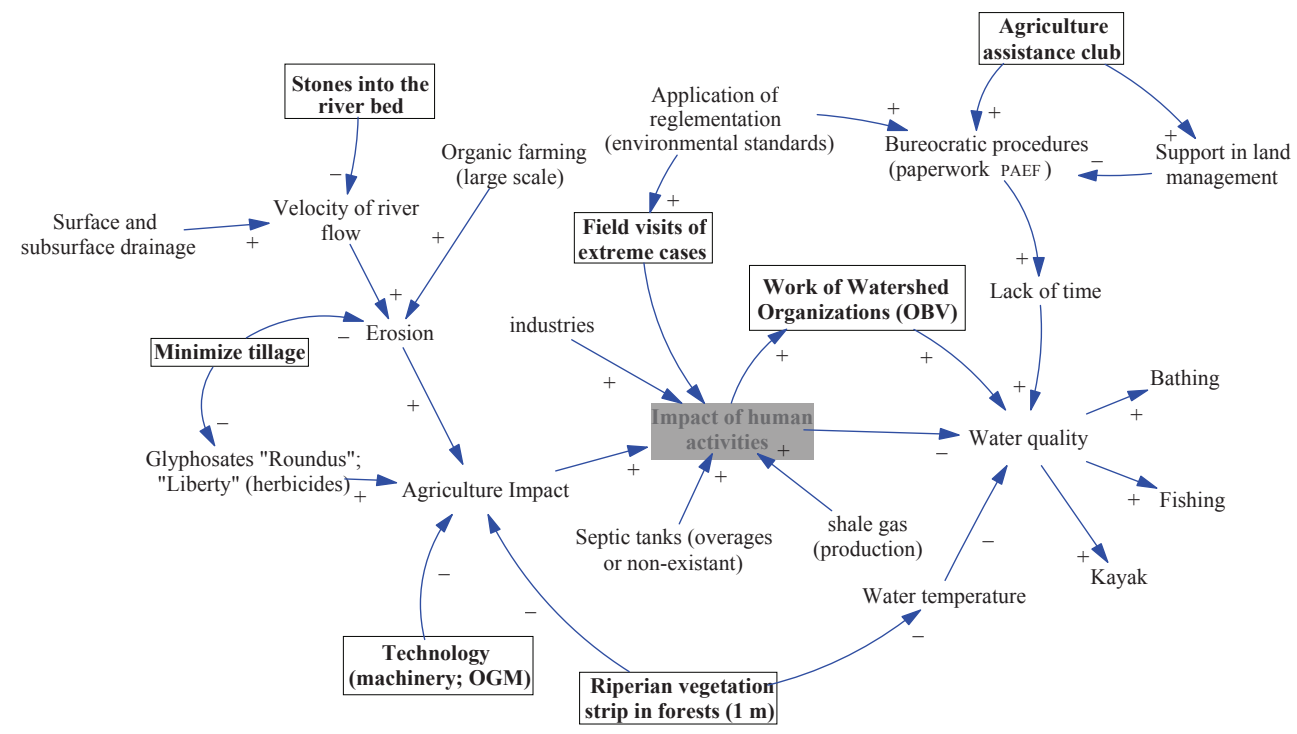

FIGURE 2. Causal Loop Diagram developed by the representative of the agricultural sector in the Du Chene wetershed

Note: PAEF: Plan Agroenvironnemental de Fertilisation.

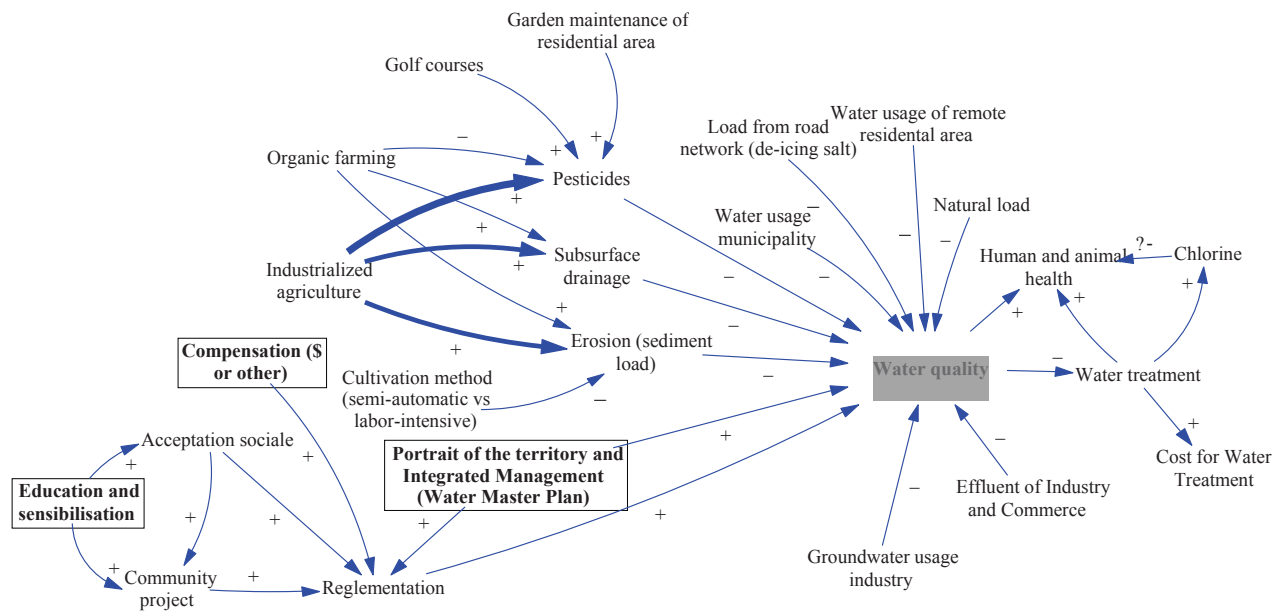

FIGURE 3. Causal Loop Diagram developed by the representative of the forestry sector in the Du Chene watershed

Note: The different line widths are used to indicate that the impact of "industrial agriculture" is higher compared to "organic farming". 


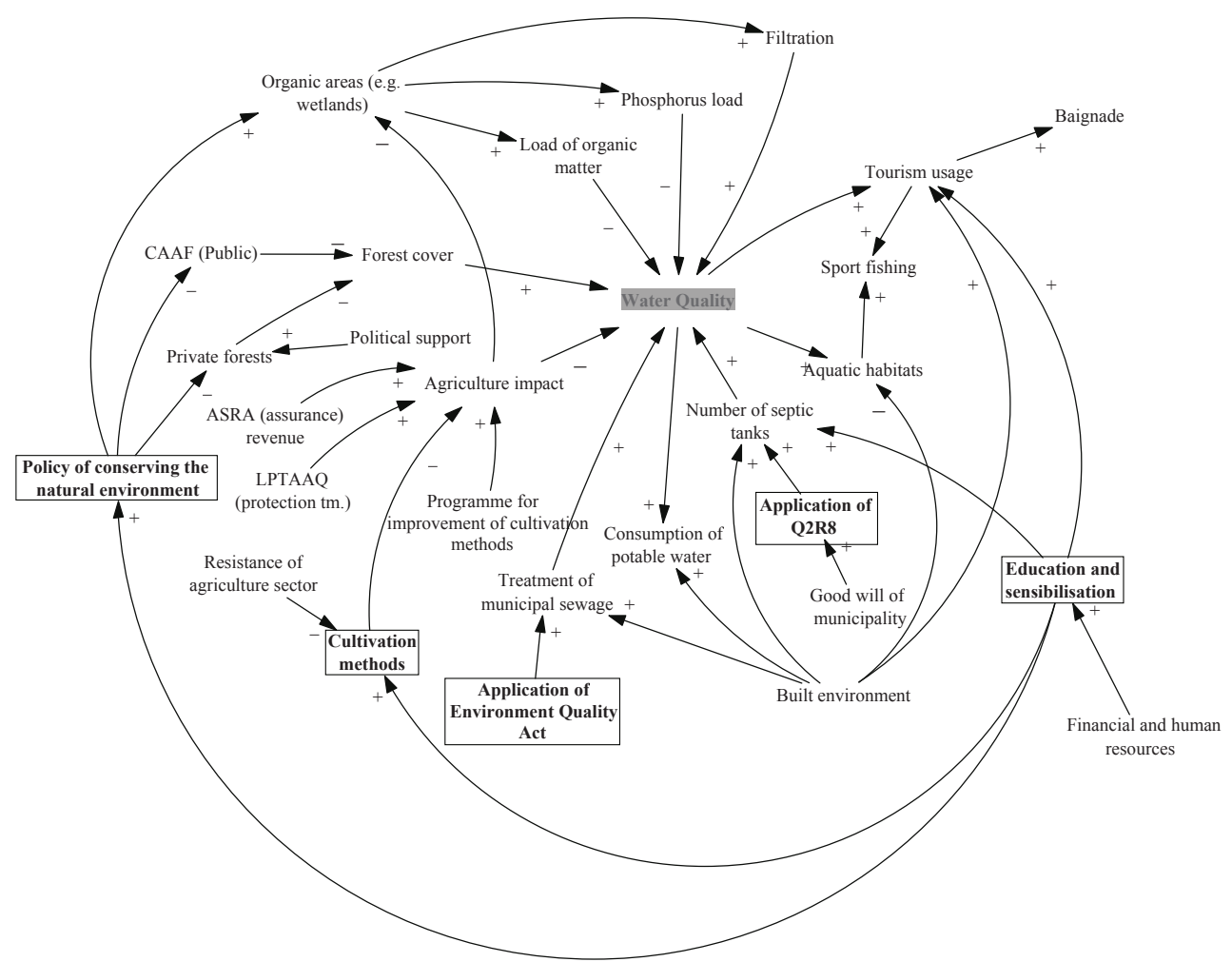

FIGURE 4. Causal Loop Diagram developed by the representative of the municipal sector in the Du Chene watershed

Note:

ASRA: Programme d'assurance stabilisation des revenus agricoles (Farm Income Stabilization Insurance Program).

CAAF: Le contrat d'aménagement et d'approvisionnement forestier (Supply contracts and forest management).

LPTAAQ: Loi sur la Protection du territoire et des activités agricoles du Québec (Law on the protection of agricultural land and activities).

Q2R8: Loi sur la qualité de l'environnement (Environmental Quality Act).

watershed proposed to minimize tillage of conventional agriculture to decrease agriculture impact. In contrast, the representative of the forestry sector proposed to implement organic farming to decrease erosion, pesticides, and subsurface drainage. The representative of the forestry sector believed that organic farming causes less erosion than conventional farming methods.

\section{Complementary elements:}

There are various complementary elements in the models. For example, some interviewees believed that recreational activities were the main cause of water quality problems in the Du Chene watershed, while others focused on water treatment or environmental concerns. In addition, the proposed solutions to the water quality problems are quite diverse. 
For example, the representative of the farming sector proposed considerably more 'practical' strategies compared to the representative of the municipality who suggested mainly 'political' approaches.

The proposed Participatory Model Building framework turned out to be accessible for all interviewees in the Du Chene watershed, and the process was considered to be helpful by the Du Chene watershed organization. The individual modeling process revealed multiple diverging points of views between stakeholders in the watershed. For example, biological agriculture was considered by one stakeholder to be a solution to the water quality problems in the watershed. However, another stakeholder believed that higher erosion and lower water quality would result since biological farming would require more tillage.

The qualitative system dynamics models had different levels of abstraction and thematic foci ranging from practical strategies such as various farming methods to more general approaches like consumer education. Overall, the goal of developing an overview of the perceptions of the main stakeholders was achieved, and a continuation of the process to the group model building stage (Stage 4) is planned in the near future.

\section{CONCLUSIONS}

The case study in the Du Chene watershed in Québec demonstrates the applicability and usefulness of the proposed Participatory Model Building Framework to help initiate participatory processes in a systematic way with stakeholders in a watershed. Causal Loop Diagrams were built in a series of interviews with the main stakeholders in the Du Chene watershed (i.e., those comprising the $\mathrm{Du}$ Chene watershed organization).

The results of this study demonstrate the diversity of perspectives regarding the water quality problem in the $\mathrm{Du}$ Chene watershed, and this highlights the critical need for participatory approaches to help solve water quality problems in the Du Chene watershed. Based upon the knowledge developed in this study, the Du Chene watershed organization (and other watershed organizations in Quebec) can begin to develop and implement a long-term participation process that goes beyond the exploratory stages (Stages 1 to 3) described in this paper, which could include the development of a group built quantitative system dynamics model (describing the socio-economic-political components of the watershed) that is coupled with a physically based model such as HEC-HMS or SWAT.

\section{Acknowledgements}

We are grateful for the assistance of Sandrine Desaulniers and Marie-Andree Boisvert of the Du Chene Watershed Organization. An NSERC Discovery Grant held by Jan Adamowski was used to fund this research.

\section{REFERENCES}

ADAMOWSKI J., HALBE J. 2010: A framework for group built social-economic-environmental system dynamics models for participatory and integrated watershed modeling. Proceedings of the Water 2010 Conference - Hydrology, Hydraulics and 
Water Resources in an Uncertain Environment. Quebec City, Canada, July 5-7. HALBE J., PAHL-WOSTL C., ADAMOWSKI J. 2010: A participatory model building framework for the stepwise implementation of collaborative water resources management. Submitted to Journal of Water Resources Research.

Isee systems, 2009: Introduction to Systems Thinking with STELLA. Lebanon, USA. SIMONOVIC S., FAHMY H. 1999: A new modeling approach to water resources policy analysis. Water Resources Research, 35 (1), 295-304.

Ventana Systems, 2007: Vensim ${ }^{\circledR}$ User's Guide Version 5. URL: http://www.vensim.com/documentation.html (retrieved, April 2009).

Streszczenie: Planowanie zarzadzania zasobami wodnymi $w$ intensywnie użtkowanej rolniczo zlewni Quebec, Kanada, z wykorzystniem modelu dynamicznego uwzględniajacego interesariu$s z y$. Rola interesariuszy jest ważnym elementem w zintegrowanym zarządzaniu zasobami wodnymi zlewni. Organizacje zajmujące się zagospodarowaniem zlewni rzecznych, w prowincji Quebec wdrażają obecnie system zarządzania zasobami wodnymi zlewni oparty na partycypacji interesariuszy, którzy zainteresowani są wykorzystaniem zasobów wodnych. Obecnie brakuje nieskomplikowanej i wygodnej we wdrożeniu metodyki uwzględnienia interesariuszy $\mathrm{w}$ zintegrowanym zarządzaniu zlewnią, w którym rozpatruje się ponadto zachodzace procesy społeczne i fizyczne. W pracy opisano zastosowanie pierwszych trzech, z pięciu etapów, nowo zaproponowanej metodyki stworzenia dynamicznego modelu partycypacyjnego, stosowanego w celu ułatwienia rozstrzygania problemów zarządzania zlewnią poprzez partycypację interesariuszy korzystają- cych z jej zasobów. W intensywnie użytkowanej rolniczo zlewni Du Chene w prowincji Quebec, przeprowadzono 8 wywiadów z interesariuszami, a następnie, przy współpracy lokalnego zarządu wodnego, przystapiono do zbudowania ilościowego modelu dynamicznego, który uwzględnia główne procesy fizyczne i społeczne w zlewni - Du Chene. Zaproponowany model partycypacji został oceniony przez interesariuszy jako przystępny oraz okazał się być użyteczny dla zarządów wodnych w celu przeglądu różnych perspektyw wkładu interesariuszy w zarządzanie zlewnia, a także ułatwił opracowanie strategii i polityki zarządzania zasobami zlewni. Model dynamicznego systemu udziałowców, zbudowany dla indywidualnych udziałowców w badanej zlewni i opisany w tym artykule, może zostać stopniowo rozbudowany do ogólnego, zbiorczego modelu, opisującego socjologiczne, ekonomiczne i polityczne procesy, istotne dla zarządzania zlewnia, oraz może zostać zintegrowany z modelami matematycznymi, takimi jak HEC-HMS lub SWAT, opisującymi fizyczne komponenty zlewni.

Stowa kluczowe: zarządzanie zlewnią, gospodarowanie wodą w zlewni, interesariusze, rolnictwo, konstrukcja systemów.

\section{MS. received March 2011}

\section{Authors' address:}

Jan Adamowski, Johannes Halbe

Department of Bioresource Engineering

Faculty of Agricultural and Environmental

Sciences, McGill University, Canada

Macdonald Campus

21111 Lakeshore Road

Ste-Anne-de-Bellevue

Quebec

Canada H9X 3V9

Telephone: 5143987786

email: jan.adamowski@mcgill.ca 